\title{
Diagnostic study of cost management in manufacturing SMEs in Colotlán Jalisco \\ Diagnostic study of cost management in manufacturing SMEs in Colotlán Jalisco
}

\author{
LOMELI-RODRÍGUEZ, Sandra Eva ${ }^{1} \dagger^{*}$, GUZMAN-AGUILAR, Ernesto ${ }^{1}$, GONZÁLEZ-OROZCO, \\ Raúl $^{1}$ and VERGARA-MESA, Gerardo Alexander ${ }^{2}$
}

${ }^{1}$ Universidad de Guadalajara, Centro Universitario de la Ciénega. Departamento de Contaduría y Finanzas.
${ }^{2}$ Universidad de San Buenaventura, Colombia

ID $1^{\text {st }}$ Author: Sandra Eva, Lomeli Rodríguez / ORC ID: 0000-0003-1161-6989

ID $1^{\text {st }}$ Coauthor: Ernesto, Guzman-Aguilar / ORC ID: 0000-0002-7640-0604

ID $2^{\text {nd }}$ Coauthor: Raúl, González-Orozco / ORC ID: 0000-0003-3742-4344

ID $3^{\text {rd }}$ Cauthor: Gerardo Alexander, Vergara-Mesa / ORC ID: 0000-0003-1764-4104

DOI: $10.35429 / J B S .2019 .16 .5 .37 .40$

Received June 21, 2019; Accepted December 30, 2019

\begin{abstract}
Cost control in companies plays a vital role in decision making, regardless of size. Before this investigation, there was no precise information regarding the situation of cost management in manufacturing SMEs in Colotlán Jalisco, Mexico. When carrying out this research work, information was obtained according to the measurement, analysis, and cost management of these companies. The methodology used was a quantitative type by applying an instrument/questionnaire to a sample of the study universe. The surveys were applied to 51 companies, which were selected in a multivariate way with respect to each economic activity. The universe of manufacturing SMEs in Colotlán Jalisco was taken from the National Statistical Directory of Economic Units (DENUE) of INEGI. The sample was calculated with $95 \%$ confidence and an error margin of $+/-5 \%$. (DENUE, 2019) By having this information, it will be possible to have indicators that will work as a basis for the generation and application of projects that have an impact on the improvement of the integral management of the SMEs under study. Projects that will be carried out in conjunction with the research group of the University of Buenaventura Colombia.
\end{abstract}

Cost, SMEs, Manufacturing

\begin{abstract}
Resumen
El control de costos en las empresas juega un papel importante para la toma de decisiones sin importar su tamaño. Antes de esta investigación no se contaba con información precisa respecto a la situación que guarda el manejo de los costos en la PYMES manufactureras de Colotlán Jalisco, México. Al realizar el presente trabajo de investigación se obtuvo información respecto a la medición, análisis y gestión de costos de estas empresas. La metodología utilizada fué de tipo cuantitativa mediante la aplicación de un instrumento/cuestionario a una muestra del universo de estudio. Las encuestas fueron aplicadas a través de la visita a 51 empresas, las cuales fueron seleccionadas de manera multivariada con respecto a la actividad económica. El universo de PYMES manufactureras en Colotlán Jalisco se tomó del Directorio Estadístico Nacional de Unidades Económicas (DENUE) del Instituto Nacional de Estadística y Geografía (INEGI). La muestra se calculó con una confianza del $95 \%$ y un margen de error de $+/-5 \%$. (DENUE, 2019) Al contar con esta información será posible contar con indicadores que servirán de base para generación y aplicación de proyectos que repercutan en la mejora de la gestión integral de las PYMES objeto de estudio. Proyectos que se llevarán a cabo en conjunto con el grupo de investigación de la Universidad de Buenaventura Colombia.
\end{abstract}

Costos, PYMES, Manufactureras

Citation: LOMELI-RODRÍGUEZ, Sandra Eva, GUZMAN-AGUILAR, Ernesto, GONZÁLEZ-OROZCO, Raúl and VERGARA-MESA, Gerardo Alexander. Diagnostic study of cost management in manufacturing SMEs in Colotlán Jalisco. Journal of Bussines and SMEs. 2019. 5-16: 37-40

\footnotetext{
*Correspondence to Author (email: sandylome@ hotmail.com)
}

$\dagger$ Researcher contributing first author. 


\section{Introduction}

The northern region of Jalisco is made up of 10 municipalities; the one with the most significant economic development is Colotlán Jalisco. It is one of the least populated regions since, according to the Institute of (INEGI, 2005), it only has $1.1 \%$ of the total population of the state. A large part of its population is of the Huichol ethnic group.

In this zone, the economic development has been deficient, so with this investigation, we intend to make a diagnosis that serves as a basis for projects aimed at the development of the region. Specifically, the study is carried out in the municipality of Colotlán Jalisco.

Colotlán is a municipality and town in the Northern Region of the State of Jalisco, Mexico. This area is one of the least populated regions of Jalisco. It has an extension of 10,360 $\mathrm{km} 2$, which represents, as already mentioned, $1.1 \%$ of the total population of the state. The node municipalities are Colotlán and Huejuquilla el Alto.

Colotlán had a total of 6,008 economically active individuals in the year 2000. The manufacturing sector employs the plurality of this population (30.6 percent), followed by the commercial sectors (wholesale and retail) 13.6 percent, while agriculture and livestock 12.0 percent. Currently, there are 172 manufacturing companies according to data from the National Statistical Directory of Economic Units - INEGI (2019). Of these manufacturing companies, 163 have from 0 to 5 workers, 7 have from 6 to 10 workers, and only 2 companies have from 11 to 20 workers.

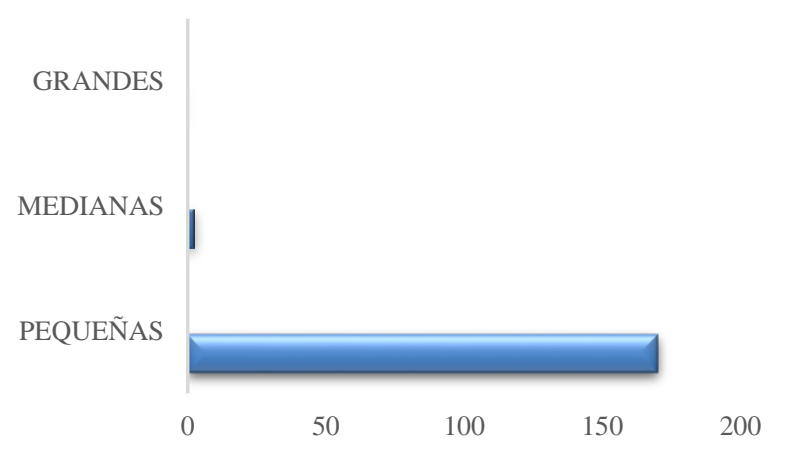

Graph 1 Manufacturing companies in Colotlán Source: DENUE(2019)
This investigation focuses on manufacturing SMEs, specifically on cost control.

Costing management in companies of all sizes plays a vital role in decision making. With this research, the current situation of cost management in manufacturing SMEs in Colotlán Jalisco, Mexico, will be accurately known.

The general objective is then to generate a diagnosis on the current cost systems or cost programs of the manufacturing SMEs in Colotlán Jalisco.

With this information, it will be possible to have indicators that will serve as a basis for the generation and application of projects to improve the comprehensive management of the SMEs under study. Projects that will be carried out jointly with the research group of the University of Buenaventura Colombia.

The first part of the article explains the importance of cost management for decisionmaking in enterprises. The second part presents the methodology used to apply the diagnosis, to continue with the presentation of results, and to close with the conclusions.

\section{Cost management}

So far, in the 21 st century, a time of significant development in the use of technology, the Internet, and the maturation of globalization, relevant changes can be observed in the fiscal, economic and financial fields of companies worldwide. Also, there is intense business competition, handling of cutting-edge electronic information, and new forms of marketing. These are aspects that Management Accounting cannot ignore.

According to him (Arredondo, 2015), "cost accounting supports financial accounting and management accounting to provide information on costs and expenses for decision making."

Likewise, (Valeria \& Soto, 2017) state that cost indicators serve for the control, evaluation, completion, and development of cost information systems for organizations. 
To start from a solid base, it is determined that the cost system is integrated by the following phases: The first is the Cost System (CS), which produces data that should be useful for the management and formulation of projects; and the second phase is the Output data which is integrated into the Cost Information System (CIS) which includes strategic data for the measurement, analysis, and management of costs. It can be understood more clearly in Figure 2:



Figure 2 Cost information system

Source: Prepared by the authors (2019)

\section{Methodology}

Population. 172 entrepreneurs from SMEs dedicated to manufacturing in the municipality of Colotlán Jalisco, Mexico, were identified as the study universe.

For the development of the companies, it is necessary that the generators of information know precisely how to determine their costs, for correct decision making.

Sample. Obtained through proportional probability sampling, the number of entrepreneurs of manufacturing SMEs was determined, considering the data: size and subsector to which the company belongs. (Bernal, 2010)

The statistical sample determined that 51 surveys were applied, with a degree of reliability of $95 \%$ and a margin of error of +/$5 \%$, which were applied in a multivariate way concerning the economic activity carried out by the SMEs.

Instruments. A 22-question questionnaire was constructed to obtain the required information in an objective and reliable manner.

\section{Results}

In Colotlán of the 172 manufacturing companies: $26 \%$ are from the food and beverage industry, $46 \%$ tanning and finishing of leather and fur (saddlery), 7.5\% carpentry, 9\% marble and brick and the remaining $11 \%$ from others.

$70.6 \%$ of its owners are male, and only $29.4 \%$ female.

The level of schooling of the entrepreneurs $41.2 \%$ finished high school, $19.6 \%$ high school, $27.5 \%$ elementary school, $7.8 \%$ university studies, $2 \%$ master's degree, and $2 \%$ have no academic preparation.

The age range of entrepreneurs is very varied: from 18 to 25 years $7.8 \%$, from 26 to 30 years $11.8 \%$, from 31 to 35 years $9.8 \%$, from 36 to 40 years $13.7 \%$, from 41 to 45 years $23.5 \%$, from 46 to 50 years $11.8 \%$ and over 50 years $21.6 \%$.

Production lines that handle: 1 line $12 \%$, 2 lines $47.9 \%, 3$ lines $18.7 \%$ and 4 lines $20.8 \%$.

Organized their production processes: $2 \%$ not and $94 \%$ if they have identified their production processes. However, they have no record of it. They manage it intuitively.

Process Map: $94.1 \%$ do not have the supports, graphics, or digital formats. Only $5.9 \%$ do.

Classification of activities: $84.3 \%$ do not have identified and classified activities and only $15.7 \%$ if they have it in a rudimentary way.

Certainty in the calculation of costs: $86.3 \%$ have uncertainty in the calculation of costs, and only $13.7 \%$ consider that they calculate them with certainty.

In the question, How do they do it? The answers were: Because the price is determined based on what each product generally sells for, I have a craft house that calculates it for me by telling me approximately how much it costs, because I calculate the costs at the time of selling, because I have many years making them and I know how much it costs to make a belt. 
Those who answered that they have cost control, $70.6 \%$ consider using the system of costs by orders, $23.5 \%$ by processes and the rest none; $74.5 \%$ do not use any software for the process of accumulation of costs, the remaining $25.5 \%$ affirm they use excel, contpaqi, other; $91 \%$ do not have indicators for the measurement and management of costs; $94.1 \%$ do not prepare financial statements or cost statements by product line, nor do they calculate profits by product line; $97 \%$ of companies do not have standardized forms for the preparation of products; $98 \%$ do not calculate the cost of waste. No company has analytical protocols for the engineering area.

\section{Acknowledgments}

The present project was carried out with the collaboration of three students from the DELFIN 2019 Research Summer.

\section{Conclusions}

In reviewing the results, it was concluded that the small and medium-sized manufacturing companies in Colotlán Jalisco do not have systems for calculating the costs of the products they manufacture. Therefore, it is necessary to establish projects that help with cost management in manufacturing SMEs in Colotlán, as well as the generation and implementation of projects that have an impact on improving the comprehensive management of SMEs.

Establish a business incubator to support the development of training programs for existing and new companies in the northern area of Jalisco.

\section{References}

Arredondo, G. M. (2015 ). Contabilidad y análisis de costos. Mexico: Grupo Editorial Patria.

Bernal, C. A. (2010). Metodología de la Investigación, administración, economía, humanidades y ciencias sociales. Colombia: Pearson Educación.
DENUE . (August 30, 2019). Directorio Estadísticio Nacional de Unidades Económicas. Obtenido de Instituto Nacional de Estadística y Geografía: https://www.inegi.org.mx/app/mapa/denue/

INEGI. (December 31, 2005). Instituto Nacional de Estadística y Geografía. Obtenido de Conteo de Población y Vivienda: https://www.inegi.org.mx/programas/ccpv/2005 I

Valeria, G. S., \& Soto, C. (2017). Contabilidad de Costos. Mexico: ECOE. 